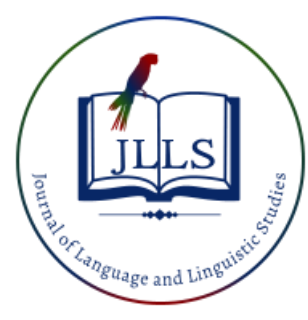

Available online at www.jlls.org

JOURNAL OF LANGUAGE

AND LINGUISTIC STUDIES

ISSN: 1305-578X

Journal of Language and Linguistic Studies, 17(2), 842-868; 2021

\title{
The determination of Turkish and Turkish language and literature teacher candidates' awareness of learning grammar
}

\author{
Esra Ekinci Çelikpazu a 1 iD, Elif Atalay ${ }^{\text {b }}$ iD \\ ${ }^{a}$ Recep Tayyip Erdoğan University, Rize , Turkey
}

APA Citation:

Ekinci Çelikpazu, E., \& Atalay, E. (2021). The determination of Turkish and Turkish language and literature teacher candidates' awareness of learning grammar. Journal of Language and Linguistic Studies, 17(2), 842-868. Doi: 10.52462/jlls.59

Submission Date:26/02/2021

Acceptance Date:20/05/2021

\begin{abstract}
This study aims to determine the direction what the mother tongue teacher candidates' awareness of why they learned grammar/features of the structure of the language. The research was conducted according to the document analysis method in qualitative research principles. The study group consisted of 94 students studying in the 1st, 2nd, 3rd, and 4th grades of Turkish teaching and Turkish language and literature in the 2019-2020 academic year of a state university. As a method of data collection, the participants were asked to answer an open-ended question that was prepared and standardized in advance by the researchers in writing to create a comprehensive text. The texts created with this method were used as the documents of the research. The data analysis method of the research is a categorical analysis which is one of the content analysis types. The awareness of the study group on the subject determined was combined into six themes. According to the results, the study identified various awareness of prospective teachers of Turkish and Turkish language and literature regarding the formation of language awareness as; development of understanding skills, development of expression skills, language-reality relationship, functional language use, and thinking-language relationship were determined regarding learning the structural features/grammar of Turkish.
\end{abstract}

Keywords: Grammar; awareness; teacher candidates; Turkish language; learning.

\section{Introduction}

The student who cannot fully learn what grammatical concepts are in the Turkish lessons given at schools and cannot establish a relationship between them, chooses to memorize the concept. However, language is a structure/system, and the teaching of language cannot be realized by teaching independent forms alone (Börekçi, 2009). Students can learn the real world through language only if they can analyse the relationships between parts in the language. For this reason, there is a need for a grammar/language teaching that shows the relations and functions of the parts in the language system, not the individual parts. Formal, semantic, and pragmatic explanations are required while teaching grammatical concepts to students in Turkish/Turkish language and literature classes in schools (Ekinci

\footnotetext{
1 Corresponding author.

E-mail address: esra.ekinci@erdogan.edu.tr
} 
Çelikpazu, 2015). In this way, students in schools are expected to have an awareness of why they learn grammar in Turkish/Turkish language and literature lessons.

\subsection{Literature review}

When it comes to grammar, the rules about language and the functioning of these rules are evoked in the minds. However, language is not a set of rules. Although it is defined in different ways, language is a coherent, orderly, understandable, and explainable set of systems/strings that are more versatile than we can think of at once. This system, which establishes a relationship between human and object, enables to understand the world, then enables to share this information, to produce and increase information, to create a culture Börekçi (2009: 8). Language, considering all the features of human language; By establishing a relationship between human and object, transferring the real world to the fictional world, reflecting the logical form of the facts; reflecting the way a society perceives the world, to create and convey human thoughts; He described it as a double-articulated system built in resolvable human voices that enable him to perceive the thoughts transmitted to him.

Within this context, it has been stated that language has an active role in conveying what it produces about objective reality and even in the process of producing the idea before it is conveyed. There is thought first and then word; Based on this idea, it is not possible for an individual to create a fiction that he has not created in his mind. The individual, who creates thoughts with language with his individual use, creates himself with language and creates his own reality, his own plane (Ekinci Çelikpazu, 2015: 339).

Language: It is a double-articulated system with no sounds, words, or any stack. The first dimension of double articulation in the language is the dimension of meaning, thought and syntax. The second articulation is meaning, form and sound syntax. In Martinet (1998: 21), the double articulation of the language consisting of semantic and phonemes, which is the mechanism of forming utterances, which is obtained because of two types of analysis, which is realized with a two-stage selection action, has been expressed as one of its most distinctive features (Kerimoğlu, 2017; Korkut \& Ayırır, 2016; Bayraktar, 2006; Vardar, 2002). In addition, double articulation is the most prominent feature of natural languages and has an important place in studies on the function of language (Vardar, 2002: 61). Function, which distinguishes an element in a whole, is described as the role of a term, a suffix, a subject, a predicate, a complement in an utterance or have a function (Kıran \& Eziler Kıran, 2018). On corollary of this thought, starting from the double articulation of the language, it can be said that meaning is reached from form, and meaning becomes concrete with form.

Phonology, morphology, semantic and syntactic structures; The codes sent through the language and its units, which have interactive aspects in the processes of listening, speaking, reading, and writing, must have a certain structure to fully realize the communication. Within this structure, the meanings attributed to language units should also be formed in line with common conventions (Onan, 2011). At this point the grammar of syntax; It should be noted that grammar is also the system of the language. A language in which the syntax is not discovered cannot be expected to go beyond the 'monkey language' (Sebzecioğlu, 2016: 22). This situation constitutes the justification of both the concept of the mother tongue and the concept of the structure of the mother tongue. All languages in the world perform the process of understanding and explaining with certain rules/grammar filtered from their unique structures (Onan, 2011). Bringing individuals to a level that they can use in a learning-teaching process that supports their careful and conscious use of their mother tongue, Turkish, at the level of cognitive and affective skills included in these two processes is both among the main objectives of the Turkish Ministry of National Education and in the 2023 Education Vision (MEB, 2019). 
Grammar, which is the structure of a language, is a branch of science that studies all units of a language from sound to syntax, the structure and meaning features of these units, and the analysis of the language, and it is called the whole of the rules that need to be known to speak and write the language correctly (Karaağaç, 2012). However, since all languages have changed over time, they continue to have new structures throughout history. Therefore, it would not be right to claim that grammar rules are fixed or unchangeable, but it is undoubted that grammar has an important place in language teaching. Because, without knowing how to put words together, or when the written and spoken words come together in an irregular and complex way, a complete and correct communication cannot be achieved (Dilber, 2015: 373-374).

In the contemporary understanding of education, rather than discussions on whether grammar should be taught, discussions about which grammar subjects should be taught and how much of them should be taught, and most importantly, how grammar should be taught in a useful and effective way, come to the fore. At this point, it is necessary not to consider grammar as a collection of rules and not to memorize this group of separate rules as just knowledge, and more importantly, it is necessary to make practices aimed at gaining skills (Ar1, Okur, Yıldız \& Y1lmaz, 2008). This will contribute to the students' internalization of knowledge by considering the rules they learn in Turkish language teaching lessons, two dimensions of language, form, and meaning; It will support students in developing their ability to research, discover, interpret, and construct information in mind (Er \& Ünal, 2016).

One of the most important teachings of Saussurian structuralism is that language is a system/structure/system. The main element that keeps the system alive is the relations between the parts that make up the system. These relationships require taking meaning and form together. The function of a part in the system is more valuable than its meaning alone. This notion is also closely related to the concept of constructivism, which has been the basis for studies in education in recent years. In the constructivist language approach aimed at improving the learning and mental skills of the individual, language is learned with the active efforts of the individual and structured in the mind. It should also be emphasized that conceptual learning has a great importance here. When students learn in a holistic and meaningful way by associating facts, concepts, or any other idea with each other, what they learn is much more beneficial in their lives (Baysen \& Silman, 2012: 197-226). The knowledge of the students about the forms that make up the language system is the basis for discovering the functions of these forms in different structures and reaching new knowledge. In grammar teaching, the structure of the language should be handled in this dimension, and the student should consciously try to develop the language act materialized in the education process she encounters at school. For example, it is important for students to learn how these processes develop/support their language skills instead of memorizing the features of the structure of the language in Turkish/Turkish language and literature lessons. In the new Turkish Course Curriculum (MEB, 2019) prepared based on the constructivist approach that aims to teach by discovering knowledge, it has been noted that an effective language teaching should be carried out in this direction.

The Turkish lesson curriculum is structured in an integrity that includes knowledge and skills to provide all children in our schools acquire "listening/watching, speaking, reading, and writing" related language skills as well as cognitive skills, develop themselves individually and socially, and communicate effectively with their environment; in a way that will enable them to acquire the habit of reading and writing willingly (MEB, 2019). In the program, the grammar of Turkish was structured gradually and with an increasing intensity, considering the developmental characteristics of children in schools. In addition, Turkey qualifications framework given communication in the native language as well as the first of eight key competences; However, it has also been explained that expressing and interpreting concepts, thoughts, opinions, feelings, and facts both verbally and in writing is to interact 
linguistically in a social and cultural context in an appropriate and creative manner (MEB, 2019). In this direction, in the development process extending to language skills, grammar has an important place in the language teaching process, as it enables the meaning of the linguistic impulses coming to the brain in the comprehension process by organizing them in a certain system, and on the other hand, it helps to ensure correct and flawless thinking (Onan, 2011).

The main purpose of grammar teaching is to improve thinking, understanding, interpreting, and conveying meaning. However, the lack of use of grammar subjects taught in schools in students 'daily lives, students' thinking that they only use their knowledge of grammar in exams, and often forgetting after exams cause teachers not to give detailed explanations on this subject. It is difficult to motivate the subjects whose purpose is unknown. For this reason, students should be taught why grammar lessons are given (Aslan, 2017; Yaman \& Kararslan, 2010), and they should be helped to raise awareness in this direction.

Awareness is a part of consciousness (Searle, 2002: 66). It is to be aware of our knowledge. Being conscious of something means being able to look at it from the outside, not just inside it. Language is what makes this possible (Erkman Akerson, 2007: 32). We can convey what we have experienced/potentially experienced, events/phenomenon, facts, or dreams through language. It means we have the knowledge of everything we can convey. It means we have the knowledge of everything we can convey. Organizing information in the mind and having the knowledge of how to shape it through language encompasses cognitive processes related to thinking. The concept of metacognition refers to the individual's awareness of what he/she does not know and to develop or regulate various strategies for their own learning (Flavell, 1979). Metacognition, in its broadest sense, is defined as being aware of and controlling mental activities involved in human perception, remembering, and thinking (Özsoy, 2008: 714). Having metacognition about language can be called language awareness. However, before the concept of awareness in mother tongue and/or foreign language education, the concepts of explicit and implicit knowledge should be explained. Explicit knowledge is the kind of information that the individual learns consciously and can provide explanations about the causes of the phenomena, in other words, they can use the metalanguage function of the language. Implicit knowledge, on the other hand, is the information that an individual has unconsciously acquired and realized in his or her own language use but cannot use metalanguage about it (Büyükkantarcioğlu, 2006: 104). Considering language awareness as a prerequisite for the ability to use language consciously, it is seen that it is used in a way that includes the concepts of language ability and pragmatics. In this case, explanatory information units given in the name of language and metalanguage during the education process and consciously learned by the individual are transformed into implicit knowledge by practices and mind control over time (Büyükkantarcığlu, 2006: 105). The explicit information can usually be accessed through controlled processing. It is the conscious knowledge of grammatical rules learned through formal classroom education. Implicit knowledge, on the other hand, is unconscious, internalized grammar that can be easily accessed during written or spoken language tasks (Brown, 2000). Implicit learning occurs without the intention of learning and without being aware of what has been learned (Williams, 2005: 269). Although it is argued that explicit knowledge is internalized through frequent exposure to practice or target language, like the acquisition of other skills, according to Krashen's (1987) view, explicit knowledge is never implicit knowledge (cited in Widodo, 2006). It is not possible to develop linguistic awareness without considering the existence of the implicit linguistic knowledge acquired through the innate ability of the individual to acquire a language, and explicit knowledge in mother tongue and/or foreign language teaching can only be given by raising the level of implicit knowledge to awareness (Büyükkantarcioğlu, 2006: 104). 
The term language awareness is used in the literature to mean the consciousness and sensitivity developed by the individual against the features and use of his own language, and it is thought that this awareness and sensitivity can be gained through effective education processes (Büyükkantarcioğlu, 2006: 103). Studies on the subject have shown that students with high awareness are better at achieving their high-performance goals than those with less awareness. It was observed that awareness/explicit knowledge emerged when the students reached the linguistic rules themselves. It has been suggested that when grammar is seen/shown as a collection of rules, it will be difficult to concentrate/focus, and therefore it will not affect the formation of clear knowledge/awareness (Svalberg, 2007: 290). Since grammar descriptions are considered as abstract generalizations, they may not be of interest to students. Language awareness activities provide students with different sample experiences to reach grammatical generalizations themselves through activities such as comparison, analysis, classification, and questioning. Thus, students actively participate in the learning of the relationships between the form and function of language use (Sze \& Leung, 1998: 84). Language awareness: language teaching is a cognitive concept that includes the use of language and the communication process (Svalberg, 2007: 287) and it is possible to define this concept as an enhanced awareness and sensitivity towards different forms and functions of language usage (Carter, 2003: 64). Language awareness, which enables students to ask questions about language, collect their own linguistic data in environments outside of school, and develop an understanding of how language works as a means of transferring thoughts, is dynamic and intuitive (Tomlinson, as cited in 1994, Barjesteh \& Vaseghi, 2012: 21). It is also a cognitive process that involves exploring the formal features of language usage and establishing and expressing connections between form and function/meaning. This process overlaps with the main purpose of grammar teaching.

\subsection{Research questions}

In the literature, no study was found to determine why students learned grammar in the teaching process, in other words, to determine students' awareness of why they learned Turkish grammar. Existing studies are generally aimed at determining students' attitudes and/or perceptions towards grammar teaching (Balc1 \& Melanlıoğlu, 2020; Er \& Ünal, 2016; Özkaya \& Coşkun, 2018). In this study, it was aimed to determine the awareness of Turkish and Turkish language and literature teacher candidates (mother tongue teacher) about why they learned the grammar/features of the structure of the language. In this sense, it is thought that the research will contribute to the deficiency in the literature.

\section{Method}

A descriptive approach was adopted in this study to determine whether Turkish and Turkish language and literature teacher candidates have awareness of why they have learned the characteristics of Turkish structure/grammar during the teaching process. The research was constructed according to qualitative research and carried out by document analysis method. Document analysis is a frequently preferred method in linguistic studies. In qualitative research, when it is not possible to collect data through direct observation and interview, the documents provide information to the researcher about many unobservable situations by presenting a rich data source (Patton, 2014: 293).

Documents are materials that are available in all kinds of written or printed forms (Fraenkel, Wallen \& Hyun, 2011: 537). In an educational research, textbooks, curriculum programs, lesson plans, student assignments, written documents, individual files kept about students, etc. all official and private sources on education can provide a rich data source (Bogdan \& Biklen, 2006). 
It is also important for the document analysis to obtain a different perspective from the data sources that the researcher focuses on without the need for observation and interviews, and to provide such a rich data, in terms of ensuring the internal validity (credibility) of the research (Turgut, 2014). Bowen (2009: 27) used the document analysis, which includes the analysis of written materials that provide data about the context in which the participants are active, in his research, which includes information about the main phenomenon that is aimed to be researched, in a qualitative research, and named it as document analysis. Document analysis is also used together with other data collection methods in terms of diversifying data (Yıldırım \& Şimşek, 2016: 189).

In document analysis, which aims to reveal what is not seen from the outside, it is decided which documents will be examined in line with the purpose of the research or the research question (Cansiz Aktaş, 2014: 364). In document analysis, direct quotations from the obtained data are used to ensure external validity (transferability) and a detailed description is achieved in this way. To achieve high internal validity, it is ensured by checking the consistency of the data collected by the researcher with the results obtained in the process of determining the coding categories by another researcher.

\subsection{Sample / Participants}

In qualitative research, the study group is the individuals or groups that have the quality to solve the research problem and are thought to be useful in discovering and explaining the events and facts (Yıldırım \& Şimşek, 2016).

For this study, criterion sampling, one of the purposeful sampling methods, was used while the study group of the research was formed. Participants who have received the undergraduate level in Turkey and Turkish lessons to be voluntarily participated in the study were identified as criteria. In this context, the study group consists of 1 st, 2nd, 3rd, and 4th grade students studying in the department of Turkish language teaching at a state university in the 2019-2020 academic year, and the Turkish language and literature department students who receive pedagogical formation education. The number of participants in the study is 94 and their demographic characteristics were not included in the scope of the study.

\subsection{Data collection procedures}

As a data collection method in the study, the participants were asked to answer an open-ended question that was prepared and standardized beforehand by the researchers in writing to create a comprehensive text. With this approach, the researchers had the opportunity to catch the participant's sincerity in the texts they wrote. Participants constituted the study group, were asked to explain in writing about their view of the Turkish language and literature and Turkey Turkish lessons to the structure/languages that have been taught for the knowledge they learned, leaving traces in their minds throughout the educational experiences of positive and negative samples (feelings, thoughts, and behaviour). Awareness expressions stated in the texts of the participants were systematically categorized to provide hints for the writing of awareness items.

\subsection{Data analysis}

The content analysis method, one of the qualitative data analysis methods, was used in the study. Content analysis involves creating categories, counting certain elements in a text or image based on the situations in which they are associated with the created categories (Silverman, 2018). In Patton (2014: 453), content analysis is defined as an attempt to reduce and make sense to any qualitative data to determine the basic consistencies and meanings by taking the qualitative material, which is a large 
text set. In a qualitative research, code is an associative word or short expression that is often used as a symbol to describe language-based qualitative data (Saldana, 2019). However, attention should be paid to the fact that the code used in this context is summarizing, striking, and reflecting the essence / main subject. Coding is the key link between data collection and interpretation (Charmaz, 2015). Silverman (2018) states in the content analysis that the researchers create a series of categories and then count and record the situations falling into each of these categories. However, he also states that the most important point is that different coders should create clear and transparent categories that will enable them to achieve the same results. Therefore, the content analysis should be defined as a repeatable, systematic, technique.

While analysing the data of the research, the information obtained from participants were symbolically coded such as "Ö1, Ö2, S3, ...". The obtained data were analysed in accordance with the categorical analysis method. The categorical analysis is based on first dividing a certain message into units and grouping these units into categories according to certain criteria (Bilgin, 2014). Before creating the categories, word groups or expressions and sentences (Baş \& Akturan, 2013) were determined as analysis units. Codes were created based on these units. Later, the codes that are like each other and related (Merriam, 2013) were classified and the categories were reached. The codes were created together at the same time by the researchers and combined in appropriate categories. Then, documents with written texts were examined by another Turkish education expert, and it was seen that similar categories were reached. Theme names were created based on the categories. Again, for the reliability (consistency and verifiability) of the study, direct quotations from the individuals in the study group were included in the data analysis process (Yıldırım ve Şimşek, 2016).

\section{Results}

This section will present the findings obtained from the analysis of the research. After the content analysis, teachers' awareness of why they learned grammar was presented under six themes: "the formation of language consciousness, the development of comprehension skills, the development of expression skills, the understanding of the language-reality relationship, the use of functional language, and the relationship between thinking and language".

Table 1. Awareness of language consciousness

\begin{tabular}{|c|c|c|c|c|}
\hline Theme & Category & $\mathrm{f}$ & $\%$ & Participants' codes \\
\hline & $\begin{array}{l}\text { learning the structure of the } \\
\text { language system }\end{array}$ & 17 & 20,2 & $\begin{array}{l}\text { Ö2, Ö6, Ö37, Ö42, Ö46, Ӧ47, } \\
\text { Ö48, Ö49, Ö52, Ö53, Ö55, } \\
\text { Ö56, Ö61, Ö63, Ö67, Ö68, Ö81 }\end{array}$ \\
\hline & Preserving Language & 17 & 20,2 & $\begin{array}{l}\text { Ö6, Ö23, Ö32, Ö37, Ö43, Ö45, } \\
\text { Ö47, Ö48, Ö51, Ö52, Ö53, } \\
\text { Ö56, Ö61, Ö64, Ö73, Ö83, Ö84 }\end{array}$ \\
\hline & $\begin{array}{l}\text { Understanding } \\
\text { characteristics/beauties of } \\
\text { the language }\end{array}$ & 16 & 19 & $\begin{array}{l}\text { Ö2, Ö25, Ö30, Ö33, Ӧ37, Ö40, } \\
\text { Ö42, Ö48, Ö53, Ö56, Ö63, } \\
\text { Ö66, Ö69, Ö80, Ö81, Ö82 }\end{array}$ \\
\hline & Learning culture/adopting & 7 & 8,3 & $\begin{array}{l}\text { Ö22, Ö43, Ö47, Ö48, Ö53, } \\
\text { Ö61, Ö84 }\end{array}$ \\
\hline Language & Historical awareness & 7 & 8,3 & $\begin{array}{l}\text { Ö48, Ö51, Ö61, Ö78, Ö79, } \\
\text { Ö81, Ö82 }\end{array}$ \\
\hline
\end{tabular}




\begin{tabular}{llllll}
\hline Awareness & $\begin{array}{l}\text { Development } \\
\text { Individual/society }\end{array}$ & of 4 & 4,7 & Ö43, Ö73, Ö78, Ö84 \\
\cline { 2 - 5 } & $\begin{array}{l}\text { Ensuring language Unity } \\
\begin{array}{l}\text { saving language from the } \\
\text { influence of foreign } \\
\text { language }\end{array}\end{array}$ & 2,3 & Ö31, Ö61 \\
\hline
\end{tabular}

Table 1 presents participants' awareness of the formation of language awareness. The awareness of the participants about the formation of language awareness is in the form of learning the structure of the language system, preserving the language, understanding the characteristics/beauties of the language, learning/adopting the culture, historical awareness, development of the individual/society, ensuring language unity and saving the language from the influence of foreign languages.

According to the participants ( $\mathrm{f}=17$ ) who think that the language learning is done to learn the structure of the language, when the structure of the language system is learned, the rules of the structure will also be adopted and the changes/developments in the language and history will be better understood:

Ö2. The most important reason for learning Turkish grammar is to better understand the language we speak and justify it. It is necessary to learn how the structure of our language is formed and to use it by the rules.

Ö6. To put it this way, it enabled me to learn what and where even a vowel is based on its simplest example. It helped me answer easily when people outside asked about these topics. It made me realise how systematic and fun our language has a mathematical phase.

Ö48. Turks are one of the oldest and well-established nations in the world. This situation is reflected in our language as accumulation and change. During our centuries-long history, we accepted various religions, ruled over various geographies, and communicated with various races. While all this was happening, we were affected as much as we affected others. With the developing and changing life, we have derived the words we need and quote when necessary. Sometimes, we diversified our language by making different voices from our brothers and sisters. All this change, development, and diversification constitute the structure of Turkish.

According to the participants ( $\mathrm{f}=17$ ), it is possible to preserve the language thanks to the sensitivity to use the language correctly and in accordance with the rules. When the language is protected, it will be maintained and can be passed on to future generations without deterioration.

Ö6. I think it is an important point to raise generations that are tied to their country by their language, so we have been taught to learn the structure of our language in its entirety.

Ö23. To learn a language effectively, it is necessary to learn, understand and grasp the grammar of that language thoroughly. A person who understands and grasps the grammar rules of the language can use the language effectively. It can contribute positively to the continuity of the language by obeying grammar rules.

Ö37. I tried to learn this lesson to be able to use our Turkish, which has a very rich structure, effectively and correctly, to be aware of its richness and to protect it as it was entrusted.

Ö51. Turkish is the first voice we hear from our mother and is the first experience we will pass on to our children.

Ö73. We, as individuals who are in love with language, should be able to learn every detail of the language and pass on what we have learned to future generations. If we can succeed in this goal, each of us can become meaningful individuals belonging to this homeland. 
Participants ( $\mathrm{f}=16)$ think that they learn the beauties and features of the language as well as the structure in the grammar teaching process. At the same time, the development of this thought can be considered as an awareness of learning the structure of the language. Because the participants stated that the more, they learned the structural features of the language, the more they became aware of its beauty:

Ö25. Learning grammar provides an awareness of language in a person. If a person understands the grammatical features of Turkish with curiosity and enthusiasm, then he/she becomes aware of the beauties of Turkish.

Ö40. I can explain the benefits of Turkish grammar lessons that I have been taking throughout my education life as follows; I learned in grammar lessons of Turkish that we are extremely lucky when we compare the richness of Turkish, our mother tongue, the ease it offers us and with other foreign languages.

Ö66. The effort to find the root of the words and reach their meanings by running like a hunter after words that I did not know or understand made me happier. We always said we had a very rich language, but when I was more deeply interested in words, I realized that Turkish was even richer than I thought.

It is also noted that the learning about grammar creates awareness of the language-culture relationship among the participants $(\mathrm{f}=7)$. According to the participants, the structural features of the language reflect the cultural identity of the society speaking that language. This awareness of identity is effective in protecting and maintaining both the society and the language of the society:

Ö22. Learning grammar enables a person to use their language fluently and clearly, to better adopt their culture, to improve their word pronunciation and vocabulary.

Ö43. As a result, for a society to develop and keep its culture alive, it must preserve and develop its language consciously. For this, everyone in society should learn the features of its language and grammar and use these learned carefully in all areas of life.

Ö84. Language must be known and taught. The language that creates and sustains societies also creates culture. The grammatical structure and all kinds of features of a language are the wealth and identity of that society.

According to the participants ( $\mathrm{f}=7)$, the changes in the structure of the language and the forms that make up the structure also reflect the historical adventure of the society speaking that language. The relationship of language with history is, of course, an undeniable fact. The findings reveal the participants' awareness of this fact:

Ö48. Grammar is an indication that we are not alone in the world, but our siblings. Grammar is the code that we are a deep-rooted and powerful civilization. Grammar is living proof of what we have experienced on the stage of history.

Ö61. We know that the language of a nation goes through the same historical process as people belong to that nation. People and language, who have gone through similar historical, social, and economic processes, give us clues about our history, and those who do not know their history have no future.

Ö51. We learn our past in Turkish, and we will run into the future in Turkish. While doing this, we should not ignore the rules of Turkish. We are the guardians of the Turkish language, as we protect it, it protects our independence.

Ö79. However, this process continues somehow. These rules and patterns are imposed on students, but their importance is not emphasized. Language means the foundation of the nation. The 
structure of the language is the cornerstone of the nation's journey from the past to the future. If you know your language, you will know where you come from. You know your ancestors. Examining the structure of the Turkish language is like reaching a deep-rooted heritage piece by piece.

Participants $(\mathrm{f}=4)$ draw attention to the fact that language users who have a good understanding of the relationship between language and history, using the language consciously/knowing how the elements in the language are formed will improve both themselves and the society.

Ö73. Knowing the features of the language we speak and write helps us to improve ourselves while using this language. Using a language of unknown subtlety often paves the way for speech including expressive and elliptical sentences.

Ö78. It is impossible for a nation that does not know its history to develop with firm steps. Today, although we do not know where the word "tünaydın" comes from, we often use it. In old Turkish, it means "night". Or why the word perching overlaps with birds is unknown. It becomes more understandable when translated as "to spend the night". Like this example, it is seen that many more words are used unconsciously. This unconscious situation must be corrected for the development of a nation that does not know itself. This can only be achieved by learning the structure of Turkish.

Ö51. Before, I was saying what is the need for so much pressure so people should use the written language as they wish. As I learned, I realized that preserving language is like protecting our family. We must use the written language according to its rules. We must write it point by point, without compromising and saying nothing happens once.

Participants' awareness $(\mathrm{f}=2)$ that learning about grammar requires protecting the language from the influence of foreign languages is also among the findings. At the same time, learning the structure of the language is one of the effective factors in maintaining language unity $(\mathrm{f}=2)$ :

Ö43. Knowing grammar allows you to write and even speak more accurately. At the same time, we protect Turkish and contribute to its development. If we act with this awareness as a society, we will protect Turkish from foreign vocabularies in the globalizing world.

Ö47. Students who graduated without knowing what and why they learned, put aside what they had learned after graduation and continued to use the language they learned from the environment. They constantly took new words from foreign languages into our language. They moved away from the core of our national culture. Because they learned without knowing the purpose of teaching grammar.

Ö31. Since grammar learning is our most sacred aim, it is tried to be given from the primary education level.

Table 2. Awareness of the development of comprehension skills

\begin{tabular}{|c|c|c|c|c|}
\hline Theme & Category & $\mathrm{F}$ & $\%$ & Participants Codes \\
\hline \multirow{2}{*}{$\begin{array}{l}\text { Development of } \\
\text { comprehension } \\
\text { skills }\end{array}$} & $\begin{array}{l}\text { Correct } \\
\text { comprehension/interpretation }\end{array}$ & 22 & 26,1 & $\begin{array}{l}\text { Ö8, Ö9, Ö10, Ö12, Ö16, Ö18, } \\
\text { Ö20, Ö21, Ö24, Ö28, Ö30, } \\
\text { Ö31, Ö34, Ö53, Ö55, Ö64, } \\
\text { Ö65, Ö66, Ö70, Ö80, Ö81, } \\
\text { Ö82 }\end{array}$ \\
\hline & $\begin{array}{l}\text { Being successful in other } \\
\text { fields }\end{array}$ & 2 & 2,3 & Ö13, Ö67 \\
\hline
\end{tabular}


Table 2 presents the awareness of the participants about the development of their understanding. The awareness of the participants in this area is in the form of understanding/understanding correctly and being successful in other fields.

Participants $(\mathrm{f}=22)$ think that learning the structure of the language is effective in understanding and interpreting the texts read/listened correctly. The correct understanding is parallel with the correct learning of the structure:

Ö30. In my opinion, grammar is a field that needs to be focused on because; Sentence structure, word structure, and grammar rules and structure contribute a lot about what the sentence wants to tell.

Ö81. The structure of Turkish should become a separate lesson again, and I think that everyone whose native language is Turkish, or anyone who wants to speak and understand this language, should also go down to the language structure. No text read cannot and should not be independent of the structure of the language.

Another awareness addressed in the category of development of comprehension skills is being successful in other fields $(f=2)$. According to the participants, it is possible to be successful in lessons other than Turkish or Turkish language and literature lessons and in other areas of daily life by understanding the texts correctly:

Ö13. Our teachers always tell us that Turkish is relevant to all lessons, we should know Turkish and grammar rules well so that we can understand even the simple problem we read in mathematics.

Ö67. Yet, anticipating that someone who cannot master her or his own language to be successful in other fields cannot go beyond imagination.

Table 3. Awareness of the development of narrative skill

\begin{tabular}{|c|c|c|c|c|}
\hline Theme & Category & $\mathrm{f}$ & $\%$ & Participants Codes \\
\hline \multirow[t]{7}{*}{$\begin{array}{l}\text { Development of } \\
\text { Narrative Skills }\end{array}$} & Ability to speak correctly & 32 & 38 & $\begin{array}{l}\text { Ö2, Ö8, Ö10, Ö14, Ö15, Ö16, } \\
\text { Ö19, Ö22, Ö24, Ö25, Ö28, Ö32, } \\
\text { Ö33, Ö34, Ö36, Ö37, Ö40, Ö42, } \\
\text { Ö43, Ö44, Ö46, Ö53, Ö57, Ö64, } \\
\text { Ö65, Ö69, Ö70, Ö73, Ö74, Ö78, } \\
\text { Ö80, Ö82 }\end{array}$ \\
\hline & Ability to write correctly & 30 & 35,7 & $\begin{array}{l}\text { Ö2, Ö8, Ö10, Ö16, Ö19, Ö21, } \\
\text { Ö22, Ö24, Ö25, Ö28, Ö31, Ö33, } \\
\text { Ö34, Ö36, Ö37, Ö40, Ö42, Ö43, } \\
\text { Ö44, Ö46, Ö53, Ö57, Ö61, Ö64, } \\
\text { Ö65, Ö70, Ö74, Ö78, Ö80, Ö83 }\end{array}$ \\
\hline & Correct self-expression & 14 & 16,6 & $\begin{array}{l}\text { Ö9, Ö14, Ö16, Ö28, Ö33, Ö34, } \\
\text { Ö44, Ö47, Ö52, Ö53, Ö57, Ö73, } \\
\text { Ö74, Ö82 }\end{array}$ \\
\hline & Using language effectively & 13 & 15,4 & $\begin{array}{l}\text { Ö3, Ö4, Ö9, Ö11, Ö13, Ö15, } \\
\text { Ö22, Ö23, Ö24, Ö31, Ö33, Ö44, } \\
\text { Ö45 }\end{array}$ \\
\hline & Communicate well & 13 & 15,4 & $\begin{array}{l}\text { Ö9, Ö10, Ö33, Ö34, Ö44, Ö45, } \\
\text { Ö50, Ö53, Ö57, Ö61, Ö64, Ö74, } \\
\text { Ö80 }\end{array}$ \\
\hline & $\begin{array}{ll}\text { Using } & \text { language } \\
\text { consciously } & \end{array}$ & 8 & 9,5 & $\begin{array}{l}\text { Ö3, Ö11, Ö19, Ö22, Ö34, Ö43, } \\
\text { Ö47, Ö48 }\end{array}$ \\
\hline & Development of self- & 2 & 2,3 & Ö31, Ö50 \\
\hline
\end{tabular}


confidence

Table 3 presents the awareness of the participants about the development of narrative skills. The awareness of the participants in this area is to be able to speak correctly, to write correctly, to express themselves correctly, to use language effectively, to communicate well, to use language consciously and to develop self-confidence.

According to the participants, learning about grammar is effective for language users to speak correctly ( $\mathrm{f}=32)$. It is necessary to learn grammar for an effective, flawless speech that will impress the listener and ensure correct understanding:

Ö16. We must learn Turkish grammar to use it functionally while speaking and writing. We should make regular sentences while talking and writing. We should use what we have learned about grammar in a speech by making sentences with subject, object, and predicate, paying attention to punctuation, spelling rules, correct pronunciation, appropriate emphasis, and intonation. If we talk and write using them, we can both express ourselves verbally and in writing and become individuals who can understand what we listen and read. That is why we need to explain and show students the functions of grammar, why we learn it and what we use it for.

Ö34. Knowing grammar rules and placing this at the centre of speaking and writing is necessary to provide a strong expression in speech and writing. If we can understand correctly, this is because the language is conveyed correctly. If we can convey what we know correctly, this is because we make the correct sentences by complying with the grammar rules we have acquired and what we have understood correctly.

It can be thought that the statements of the participants with codes S33 and T69 are remarkable in terms of concretizing the general perspective of the students about teaching grammar. At the same time, although language users do not use the names of grammatical morphemes in daily communication, it can be considered as an indicator of awareness of the functions of these morphemes in the communication process:

Ö33. We learned the grammar of Turkish, but we do not use it in our social life. For example, when we meet with friends, we learned adjectives, we do not talk as if it was a beautiful topic. But we use grammar to express ourselves completely and accurately and to be understood. Grammar adds beauty to expression. We effectively speak thanks to grammar. For example, thanks to pronouns, we get rid of word repetition in a sentence.

Ö69. We must learn grammar to speak Turkish better and to minimize speech errors. However, our teachers taught us grammar lessons with the mentality of "it is ok if you don't know it". Because we could speak Turkish anyway.

Another awareness of the participants about learning grammar is being able to write correctly $(\mathrm{f}=30)$. It is necessary to use the language correctly in accordance with its structure while writing/producing written text as well as speaking. As language users, knowing how to write is as important as knowing what to write. This awareness enables to establish and maintain a standard in terms of written language. According to the participants, using the language correctly while speaking and writing also improve the awareness of taking responsibility and the ability to empathize:

Ö21. Grammar allows us to comprehend, write and make sense of words. We humans spend most of our time by listening and watching. Sometimes when we need to write about what we listen to, we use grammar. We cannot always verbalize an event or situation. For example, we have a complaint, and we will write a petition and submit it. How we write is more important than what we will write here. Here, it shows the importance of grammar. 
Ö65. Reading and writing well is an art. A text written in accordance with the rules provides both aesthetically pleasing beauty and preserves the integrity of meaning.

Ö83. In my opinion, this is why we learn grammar: Our mother tongue is Turkish, which we learn by hearing and hearing from our mother. A 2-a 3-year-old child can easily speak. There is no grammar in speaking. There is nothing right or wrong as well as standards in spoken language. In written culture, we learn grammar rules to use the language correctly. Grammar becomes complementary when we write what we want to say. Just because we speak a language does not mean that we have command of that language. Therefore, it is essential that we need to have "knowledge" about language.

Ö28. Writing by the rules develops my sense of responsibility and empathy.

Another awareness related to the development of narrative skills is being able to express oneself correctly ( $\mathrm{f}=14)$. It is possible to say that being able to speak and write correctly is also an awareness related to self-expression, but the participants also emphasized this concept. Of course, it is among the aims of language teaching to raise individuals who can think and express their thoughts correctly:

Ö14. When I started to learn grammar in primary school, I realized that to speak well and express myself in the most accurate way, I had to learn grammar in detail and place it on my mind. Learning grammar helped me a lot in forming sentences by combining the mixed words in my head properly. I realized that I express myself better when I think about it.

Ö57. Language learning is a necessary lesson for raising young people who strengthen the communication of a nation and can express themselves better. Of course, nobody will make a show of with their diploma. Educated people should show their difference against uneducated people by using their Turkish beautifully. The importance of grammar learning is hidden in this fine line.

It is also important for individuals to use language effectively ( $\mathrm{f}=13$ ) while expressing themselves verbally or in writing. This situation not only increases the effect of words but also contributes to correct understanding. It can be said that knowing and consciously using different structures in the language is effective in the formation and differentiation of individual discourse:

Ö4. Grammar is very important to use the language effectively and successfully.

Ö23. A person who understands and grasps the grammar rules of the language can use the language effectively.

Ö44. Language knowledge is very important for our students to learn the rules of Turkish, to be able to use Turkish correctly and effectively, and to express themselves effectively in writing and verbally since their primary school years.

Healthy communication ( $\mathrm{f}=13$ ), conscious use of language $(\mathrm{f}=8)$ and development of selfconfidence $(\mathrm{f}=2)$ are other awareness related to the development of expression skills. It is thought that learning about grammar improves the self-confidence of language users is one of the key findings of the study. Speaking, writing, and expressing oneself correctly by using language effectively, establishing healthy communication by using language consciously improve self-confidence in the process of using language. The statements of the participants below support this point:

Ö9. I think it is very important to understand what you read in the native language and to use the mother tongue effectively. If we cannot fully understand Turkish, it will be difficult for people to express themselves and this makes it difficult for people to get along with each other.

Ö74. Since the beginning of our education life, we learn Turkish grammar to establish a healthier and understandable communication. 
Ö3. Until now, we have learned information about the grammatical structure of Turkish lessons in various subjects and levels in primary and high school periods. The main purpose of teaching this knowledge is to use our mother tongue effectively and consciously and to be aware of some linguistic elements related to Turkish.

Ö43. As a result, for a society to develop and keep its culture alive, it must preserve and develop its language consciously. For this, everyone in the society should learn the features of own language and grammar and use these carefully in all areas of life.

Ö31. It has a very important place even in our social life. The more grammar learning goals are achieved, the more confident we will be.

Ö50. Learning Turkish grammar makes us self-confident and provides comfort in our life. The more properly we choose words, the more accurate our sentences are, the more effective and positive communication we will have.

Table 4. Awareness of understanding the relationship between language and reality

\begin{tabular}{|c|c|c|c|c|}
\hline Theme & Category & $\mathrm{f}$ & $\%$ & Participants codes \\
\hline \multirow{3}{*}{$\begin{array}{l}\text { Understanding } \\
\text { the Relationship } \\
\text { between } \\
\text { Language and } \\
\text { Reality }\end{array}$} & $\begin{array}{l}\text { Making sense of one's own } \\
\text { existence }\end{array}$ & 16 & 19 & $\begin{array}{l}\text { Ö10, Ö24, Ö38, Ö44, Ö47, Ö48, } \\
\text { Ö53, Ö58, Ö61, Ö63, Ö64, Ö73, } \\
\text { Ö77, Ö78, Ö79, Ö83 }\end{array}$ \\
\hline & $\begin{array}{l}\text { Making sense of the } \\
\text { existence of language }\end{array}$ & 12 & 14,2 & $\begin{array}{l}\text { Ö7, Ö25, Ö32, Ö37, Ö39, Ö40, } \\
\text { Ö42, Ö48, Ö51, Ö53, Ö61, Ö64 }\end{array}$ \\
\hline & $\begin{array}{l}\text { Making sense of the real } \\
\text { world/ world of objects }\end{array}$ & 2 & 2,3 & Ö18, Ö38 \\
\hline
\end{tabular}

Table 4 presents the awareness of the participants about understanding the language-reality relationship as in the form of making sense of one's own existence, making sense of the existence of language, and making sense of the real world/world of objects.

First, the one perceives the real world with the help of language and then makes sense of own existence in this reality, and finally recognizes self. Individuals learn the features of the structure of the language to exist with thoughts as an individual and to concretize this existence with language. The following expressions of the participants $(\mathrm{f}=16)$ show that their learning about grammar creates awareness of making sense of their own existence:

Ö10. We need to use the structure, subtleties, rules, and richness of our language to understand and explain it. Human beings exist in this world as much as they can use their language. I try to learn in the best way I can understand and explain my existence in this world.

Ö24. After I started my university degree, I realized that grammar lessons are very necessary to speak well, to make sense and to interpret. I understood that without language, one cannot have a world, and that we cannot meet educated and intellectual people, and that we need to know the rules and characteristics of language.

Ö53. If I were a teacher, I would make the following sentence in the first lesson of the first lesson: Friends, if you do not know your language, you do not know your existence because it is your language that explains you, explains you to people.

Ö63. Throughout the education we received, the benefits of our language were taught to us or we made a way for it. Although we sometimes went through examples, sometimes we went deeper. In this process, different ways of getting to know our language, ourselves, should be sought. It should not 
be set aside, just mentioned within the framework of certain rules. We must be open to all the benefits of this language that will prevail with us at every moment of our lives.

It is understood from the following statements of the participants that learning about grammar contributes to the awareness of making sense of the existence of language $(\mathrm{f}=12)$ :

Ö32. We can evaluate how good, sound and rooted a language is, according to the structure and rules of that language. This is why grammar is very important, and I had many traces in my mind throughout my education life. Each element of the sentence structure is very meaningful on its own. Loading that much meaning impressed me a lot.

Ö61. Our language is flawless and very rich. Just having our own language requires knowing its entire structure. It is very valuable as a language that has been used widely in all its historical adventures, allowing them to have full relationships without any issues.

Ö64. Language is an element that creates a society. Our grammar rules also support this process of existence. If these rules did not exist, perhaps the language would have vanished.

The language system reflects how its users perceive reality. It is understood from the following statements of the participants that grammar teaching, which examines language as an entity, contributes to the awareness of making sense of the real world/world of objects ( $f=2)$ :

Ö18. Language enables the beings in the universe to be conceptualized and structured by passing through certain mental processes. In this context, grammar is the discipline that deals with language by breaking down the structuring of the beings in the universe. Grammar makes the universe more meaningful by providing the conceptualization of beings in mind, establishing a connection between the fictional world and the real world.

Ö38. It seemed that they were teaching us something different from the language we spoke throughout the education system. In fact, we should have learned the things that exist in our language and even have been implied to us. Not to mention that they show us the structures that are not in our language! At university, I learned the opposite, and I understood where my existing knowledge came from and why I used it in this way. In short, while I was taught for school and exams until high school, I am now learning for myself and my life.

Table 5. Awareness of the use of functional language

\begin{tabular}{|c|c|c|c|c|}
\hline Theme & Category & $\mathrm{f}$ & $\%$ & Participants Codes \\
\hline \multirow{7}{*}{$\begin{array}{l}\text { Use of functional } \\
\text { language }\end{array}$} & $\begin{array}{l}\text { Using the language } \\
\text { according to its rules }\end{array}$ & 30 & 35,7 & $\begin{array}{l}\text { Ö1, Ö2, Ö4, Ö10, Ö11, Ö13, } \\
\text { Ö23, Ö28, Ö30, Ö32, Ö34, Ö36, } \\
\text { Ö37, Ö40, Ö41, Ö43, Ö44, Ö47, } \\
\text { Ö50, Ö51, Ö52, Ö53, Ö57, Ö61, } \\
\text { Ö64, Ö65, Ö69, Ö70, Ö72, Ö83 }\end{array}$ \\
\hline & Associating with daily life & 19 & 22,6 & $\begin{array}{l}\text { Ö5, Ö6, Ö20, Ö25, Ö28, Ö31, } \\
\text { Ö32, Ö44, Ö50, Ö52, Ö54, Ö57, } \\
\text { Ö60, Ö61, Ö65, Ö67, Ö68, Ö74, } \\
\text { Ö77 }\end{array}$ \\
\hline & $\begin{array}{l}\text { pronouncing words } \\
\text { correctly }\end{array}$ & 5 & 5,9 & Ö22, Ö30, Ö31, Ö55, Ö70 \\
\hline & $\begin{array}{l}\text { Correcting mistakes while } \\
\text { speaking/writing }\end{array}$ & 4 & 4,7 & Ö1, Ö51, Ö57, Ö69 \\
\hline & $\begin{array}{l}\text { Correct emphasis and } \\
\text { intonation }\end{array}$ & 2 & 2,3 & Ö32, Ö55 \\
\hline & $\begin{array}{l}\text { Teaching the language to } \\
\text { foreigners / learning a } \\
\text { foreign language }\end{array}$ & 2 & 2,3 & Ö52, Ö55 \\
\hline & $\begin{array}{l}\text { Enrichment of word } \\
\text { presence }\end{array}$ & 1 & 1,1 & Ö22 \\
\hline
\end{tabular}


Awareness regarding the use of functional language is presented in Table 5 as using the language in accordance with its rules is associating with daily life, pronouncing words correctly, correcting mistakes made while speaking/writing, correct emphasis, and intonation, teaching the language to foreigners/learning a foreign language and enrichment of vocabulary. Since the identified awareness is for the use of language, the communication process has been taken into consideration and evaluated in the functional use of language category.

It is seen that learning about grammar creates awareness of learning the structure and rules of the language, as well as creating awareness of using the language in accordance with the rules $(f=30)$. This awareness can be considered as an indicator that the goals of the mother tongue course, which is accepted as a course of transforming knowledge into skills, are achieved. Participants think that attention should be paid to the rules of the language as well as to learn the rules of the language:

Ö40. While I am sure that I will see the same admiration from my students while teaching this language, I have aimed to teach myself to use these rules. Turkish is a language with an amazing structure that deserves to be used correctly.

Ö44. Strengthening our communication with people is directly connected to strengthening the Turkish language we use. There are certain points in strengthening Turkish. The most important of these points is to speak according to the rules of this language. Here too, grammar comes into play. Grammar is very important for our students to learn the rules of Turkish, to use Turkish correctly and effectively, and to express themselves effectively in oral and written form since their primary school years.

Ö72. However, grammar is a structure that keeps the sentence up. For example, if there are no elements such as conjunctions and prepositions, both the meaning and the structure of the sentence will change. Without such rules, there is no such thing as a sentence. Therefore, the purpose of these rules should be explained first. Teaching should not be undertaken without understanding the purpose. I think that an individual who wants to express self-better should know the structure of Turkish very well. For this reason, I am in favour of teaching grammar rules purposefully and purposefully.

The transfer of what is learned at school to daily life is one of the most important goals of the mother tongue lesson. Acquisitions of these skills are realized both inside and outside the school environment.

It is thought that the expressions of the participants are important in that they demonstrate the general acceptance that what is learned about grammar will not come across in daily life, and that grammar is only for exams. Participants $(\mathrm{f}=19)$ are aware that, contrary to these general assumptions, what is learned about grammar is intertwined with their daily lives and that understanding language means understanding life. In addition, it is also stated that these learnings contribute to satisfying the curiosity about the language itself/structure, and the understanding of the language system to live life systematically:

Ö6. It allowed me to use it more effectively and carefully in daily life. It helped me answer easily when people outside asked about these topics. Learning grammar made it possible for me to really love the language. It made me see how systematic, entertaining, and mathematical stages of our language.

Ö20. It is quite wrong to think that grammar will only appear in exams. In schools, this perspective should be changed and the fact that grammar can be encountered in every field in daily life and its necessity should be emphasized. If I need to recall a negative memory from my past experiences, I can give an example of the thought of one of our teachers, "Grammar does not appear too much in exams anyway". 
Ö68. If I pass the exam, the information that I said will not come up again is always in my life, always in my language. While an individual who has come to university should be equipped with enough knowledge, nowadays the situation is just the opposite. The students are still in high school mood and mentality with the wrong information. Teachers are trying to demolish the mistakes and teach correct knowledge.

Ö57. Of course, we do not specify the elements of sentences when talking in our conversations, but we can use a more fluent and descriptive language than people who do not know grammar. We always have sentences that are inverted, incomplete, and have a narrative disorder, but we can also notice our mistakes. We are aware of how to make sentences to express ourselves better.

Ö77. Every child first learns their native language, but often involuntarily. So, it happens spontaneously. But family and the environment also have a great in creating language skills contribution to this. Students' acquaintance with Turkish lessons starts at the age of seven. Meanwhile, the child speaks Turkish but is not in charge of it. But in fact, he is dominant in Turkish. The child's awareness of using the Turkish language with the Turkish lessons gradually increases depending on her age and class. In other words, learning grammar makes the child or person's life more systematic.

Ö74. We need language to convey our feelings, thoughts, wishes, and complaints. During this transfer, we need to use our language to explain and understand better. Although we are subjected to a measurement of what we have learned in our education, our purpose of realizing education is not a measurement.

Ö65. With a correctly learned grammar, later life becomes much easier and more efficient.

Another awareness of the participants about what has been learned about grammar is to pronounce words correctly while speaking or reading $(\mathrm{f}=5)$. Correct and effective use of language makes it necessary to pronounce words correctly. It is also part of this skill to get emphasis and intonation right $(\mathrm{f}=2)$ :

Ö22. Learning grammar enables someone to use their language fluently and comprehensively, to better adopt their culture, to improve their word pronunciation, and vocabulary.

Ö55. Speaking a language or doing writing exercises in that language can only be done with the grammar rules including pronunciation and intonation. What is meant by pronunciation is; vocalizing words correctly, paying attention to the intonation of words by taking punctuation marks into account.

Ö32. Grammar has many benefits in spoken language. Accent intonation is very important in terms of meaning. Considering these, grammar knowledge is indispensable.

Learning about grammar requires not making mistakes in the process of language use. This point is also one of the most important conditions of effective communication. The statements of the participants below show that they have the awareness of correcting grammar mistakes $(f=4)$ made while speaking or writing:

Ö1. We found an answer to the question of why we learn these rules in proportion to my department at the university. I understood that grammar exists to use our Turkish better, to see and correct the mistakes made.

Ö69. We must learn grammar to speak Turkish better and to minimize flawed speech.

Another point about learning grammar is being able to teach the language to foreigners/learning a foreign language $(\mathrm{f}=2)$. Learning the structure of the language correctly contributes to both learning a foreign language and teaching your own language correctly to foreigners: 
Ö52. Learning and understanding the structure of Turkish well will enable us to defend and protect our own language against other languages, and most importantly, eliminate the problems we will encounter while transferring our language to other societies.

Ö55. Elements of sentences, phrases, adverbs, prepositions, and conjunctions in Turkish grammar are also important for learning the structure and language of Turkish. For example, if a British person who wants to learn Turkish does not know that the word he knows as a subject in his own language means 'özne' in Turkish and that özne is the person performing action and work in a sentence, it will be difficult to understand and speak the language.

One of the participants thinks that learning about grammar contributes to the enrichment of individual vocabulary $(\mathrm{f}=1)$. To learn the parts that make up the structure of the language system together with their meanings and functions, it is necessary to be able to analyse the relationships between the parts correctly. This is also closely related to the thought forming process. It can be said that the awareness that the correct analysis of the conceptual relations that makes up the sentence enriches the vocabulary of the learners is remarkable:

Ö22. Learning grammar enables a person to use their language fluently and clearly, to better adopt their culture, to improve their word pronunciation and vocabulary.

Table 6. Awareness of the thinking-language relationship

\begin{tabular}{lllll}
\hline Theme & Category & f & $\%$ & Participants Codes \\
\hline $\begin{array}{l}\text { Thinking- } \\
\text { Language } \\
\text { Relations }\end{array}$ & Correct thinking skills & 4 & 4,7 & Ö14, Ö15, Ö63, Ö64 \\
\cline { 2 - 5 } & $\begin{array}{l}\text { Ability to analyse linguistic } \\
\text { relations }\end{array}$ & 4 & 4,7 & Ö31, Ö36, Ö42, Ö49
\end{tabular}

In Table 6, the awareness of the participants about the thinking-language relationship is presented. Participants' awareness in this area is their correct thinking skills and ability to analyse linguistic relationships.

Eight of the teacher candidates who participated in the study emphasized the relationship between thought and language. Participants are aware that understanding grammar can only be possible by analysing the relationships between the forms that make up the language. The system works only through the relationships established by linguistic forms. Understanding the system takes place by analysing these relationships. Learning about the structure of the language contributes to the correct understanding of the language system. The full understanding of the structure depends primarily on its correct analysis. Analysing the relationships between linguistic structures can be considered as a highlevel language skill. Understanding the messages presented correctly and creating the correct messages are also related to this skill. The statements of the participants below show the awareness of learning about grammar in correct thinking $(\mathrm{f}=4)$ and analysing linguistic relations $(\mathrm{f}=4)$

Ö14. Learning grammar helped me a lot in forming sentences by combining the mixed words in my head properly. I realized that I was expressing myself better when I thought it thoroughly.

Ö15. Until now, no explanation has been made as to why we have received grammar training. We were told that we only need to learn for exams. It caused us to express ourselves with cliche. I could not see a grammar class that would guide us to think differently and express what we think in different ways.

Ö64. At the same time, language education improves people's thinking and communication skills.

Ö42. I think learning Turkish grammar is a necessary tool to make thinking skills. 
Ö31. All high-level learning only occurs when grammar is fully grasped. In this way, the issue of deep studies and evaluations should not be missed.

Ö36. Because of grammar, we were able to make more meaningful and fluent sentences. By playing word games, we made a word have more than one meaning. It is not possible to consider Turkish and grammar independently of each other. If there is no grammar Turkish will lose its meaning.

\section{Discussion}

1. This study identified 8 different issues for making language consciousness: learning the structure of the language system, preserving the language, understanding the characteristics/beauties of the language, learning/embracing culture, historical awareness, development of the individual/society, ensuring language unity and saving the language from the influence of foreign languages. According to the participants, learning the structural features of the language system also enables to access the beauty and richness of expression of the language. The recognition of the language with its historical processes improves the individual's awareness of identifying self and his or her culture through language. Learning the structure of the language will also require using the language in accordance with its rules. In this way, the necessity of protecting the language from the influence of foreign languages will arise. In this context, language awareness can be identified as learning the structure of the language, studying the changes it has undergone in the historical process and associating it with culture, providing language unity and social unity by protecting it from foreign influences by mastering the language. In fact, an important dimension of language education is to gain language awareness (Börekçi, 1997). This point confirms the views of İpek (2015), as is the case with many researchers in the literature, on language as: the success of mankind in the fields of civilization, culture, literature, art, music, etc. that man has realized throughout history is due to language. In short, man owes his whole existence to language. All human achievements in science, art, technique, and literature are products of language. The effective use of language is a principle for civilized man. Our correct communication with the people we face depends on this principle. Good use of language means having language awareness.

2. One of the functions of grammar teaching is that it enables to analyse and convey meaning correctly. Another finding of the study is the determination of the participant's awareness of the development of their comprehension and expression skills through grammar teaching. Understandability for grammar teaching is stated in Swan (2002) as one of the two valid reasons together with acceptability (cited in Dilber, 2015). According to the participants in the research, learning grammar provides correct understanding/meaning which leads to success in other fields. Because the skill of analysing the texts correctly is closely related to the achievements at school and in life. The linguistic skills supported by grammar teaching are phonetic, morphological, syntactic awareness, vocabulary, and the skills of undeverbal/written pressing verbal/written language that requires the combined use of these skills. It has been demonstrated in different studies that grammatical awareness is effective on the development of comprehension and expression skills. For example, phonetic awareness is at the centre of the reading process and is an important skill especially for word decoding acquisition (Güldenoğlu, Kargın, Gengeç \& Gürbüz, 2019: 5). At the same time, the results of a study conducted by Güldenoğlu, Kargin, and Ergin (2016) showed that students with good phonological awareness levelled words faster and had higher reading comprehension scores than students with poor phonetic awareness. In a different study, it was concluded that upper language awareness is necessary for successful reading performance, and a consensus was reached that phonetic awareness, one of the upper language awareness skills, is the strongest predictor of reading skills (Sayar \& Turan, 2012: 50). Both phonetic awareness and sensitivity to morphological structure 
emerged as important factors in students' linguistic decoding skills (Mahony, Singson \& Mann, 2000: 191).

In a study where the relationship between morphological awareness and text interpretation was tried to be explained through French foreign language exam texts, it was predicted that it would make a significant contribution in the form of morphological, syntactic, and semantic form, all question texts have been examined, to predict the meaning of the word in the texts, to establish a word/conceptual relationship, etc. ways, morphemes, words, the relationships that words establish with each other, the relationships between words and other units, transitions and connections between sentences and so on. The coherent structures of the logical relationships between the thought units of the reader/learner in the text of morphological awareness within the framework of evaluated, typical examples (Can, 2016: 11). Tyler and Nagy (1990), on the other hand, reported that students with a good reading level used their grammatical knowledge better in words with derivative suffixes than poor readers in their study, in which they examined the level of vocabulary-semantic and syntactic knowledge of high school students. Carlisle (2000) stated that morphological awareness is the basis of the ability to parse words and analyse constituent morphemes to construct meaning, as it contributes to reading. In her research, she examined the relationship between third and fifth-grade students' awareness of the structure and meanings of derived words and the relationship between these morphological forms of awareness and word reading and reading comprehension. The results were found to be valuable in terms of showing that morphological awareness is significantly related to the ability to define the structure of complex words and contributed to the success of reading comprehension. Nakatani (2005), in his research examining the effect of increasing language awareness on students' verbal communication strategies, concluded that students with high language awareness produce longer sentences and control the message they convey. Francis (2002) suggested that language awareness facilitates writing skills.

In a study in which the relationship between morphological awareness and interpretation of the text was tried to be explained through French foreign language exam texts, morphological, syntactic, semantic, and so on. Predicting the meaning of the word in the texts, establishing a word/conceptual relationship, etc. morphology, words' relationships between words and other units, transitions, and connections between sentences have been evaluated. Within the framework of the examples discussed, it has been suggested that morphological awareness will make a significant contribution to the reader/learner in making sense of the logical relationships between thought units in the text (Can, 2016: 11).

Similarly, there are studies showing that syntactic awareness is significantly associated with both reading fluency and reading comprehension performance (Deacon \& Kieffer, 2018; Brimo, Apel \& Fountain, 2017; Brimo, 2011; Cain, 2007; Mokhtari \& Thompson, 2006). Syntax awareness is explained as the way of understanding the internal structures of the language, which is acquired initially at a young age until the preschool period, rapidly and intensively developed during the school period (Snow, Burns \& Griffin, 1998). Since it is related to the ability to think structure rather than the meaning of a sentence, it can be explained as a linguistic skill different from understanding or producing a sentence (Cain, 2007). Based on the thought that syntactic awareness develops intensively during the school period in the studies examined in the literature, it has been observed that the studies mostly focus on children in the primary, secondary, or high school age group. Especially in the research conducted by Brimo (2011) with 180 students of 9th and 10th grade, confirms the important contribution of syntactic awareness to reading comprehension.

3. According to the results of the research, the awareness about the development of the expression skill is the ability to speak correctly, to write correctly, to express oneself correctly, to use language effectively, to communicate well, to use language consciously and to develop self-confidence. It can be considered that the awareness in this area is remarkable in terms of embodying the general point of 
view of the students regarding grammar teaching. Although language users do not use the names of grammatical morphemes in daily communication, it has been observed that they are aware of the functions of these morphemes in the communication process. Knowing how to tell, whether verbal or written, is also about knowing the features of the structure of the language. The presence of such awareness in the participants can be considered as a concrete example that grammar teaching contributes to comprehension and expression skills (Aslan, 2017: 33). Although this research primarily did not focus on the effect of grammatical awareness levels on comprehension and expression skills, some studies in the literature produced results on this subject. In a study, it was pointed out that upper language awareness skills positively affected the writing skills, and it was suggested that students with high language awareness were more successful in writing skills (Batur \& Beyret, 2015: 889). It was concluded that the semantic awareness levels of middle school students were higher than their morphological awareness levels. It is a remarkable awareness that stems from learning about grammar, speaking/writing correctly, expressing oneself correctly by using language effectively, establishing healthy communication using language consciously develops self-confidence in language use. This particular finding of the study can be considered as an indication that Hudson's (1992) 's justification of grammar teaching as "creating linguistic self-esteem and self-confidence" (cited in Aydın, 1997: $24)$ is confirmed.

4. Awareness is addressed in the topic of comprehending the relationship between language and reality; It is in the form of making sense of one's own existence, making sense of the existence of language, and understanding the real world/world of objects. It is mainly because of language that a person first perceives the real world and then makes sense of his/her own existence in this reality. It contributes to exist with thoughts as an individual and to concretize this existence with language, to create a perspective against language and language-related learning. While individuals make sense of their own existence through language, they also make sense of the existence of language and its contribution to their existence as an individual. The feature of the double articulation of the language and the necessity to reflect this feature to grammar teaching is undoubtedly effective in making sense of the existence of the language together with its structure. Beyond being a means of communication, the function of a language as "transferring the real world to the fictional one" (Börekçi, 2009) makes it necessary to accept that it as a system and a tool for analysing the relations of the parts that make up the whole structure. Because the language system is the concrete form of how those who use it to see reality. Within this context, grammar teaching takes the language system as an entity and examines it. As teacher candidates, the awareness of the participants to make sense of the real world/world of objects through language is also a sign of how they will teach grammar.

5. This paper evaluated awareness under the topic of functional language use as follows: Using the language according to its rules, associating it with daily life, pronouncing words correctly, correcting mistakes made while speaking/writing, correct emphasis, and intonation, teaching the language to foreigners/learning a foreign language and enriching vocabulary. These points are evaluated under this topic as it is directly related to the use of language.

Conveying the meaning in the mind requires establishing correct relationships between words and concretizing them in accordance with the rules of the language. Accurate analysis of the established relationships ensures that linguistic mistakes are also recognized and corrected. These actions are intertwined with each other. The difference in awareness at this stage is that learning about grammar contributes to the development of vocabulary. Grammar constitutes the basis of language skills such as listening, speaking, reading, and writing. Grammar in listening and speaking plays a crucial role in comprehending and expressing spoken language (i.e., expressions) as it is deemed necessary to learn the grammar of a language, gain the ability to produce grammatically acceptable expressions in the language. Grammar in reading means students understand with which linguistic relationships 
messages are constructed; In writing, it enables students to express their ideas in clear expressions and thus to successfully communicate in writing. Finally, if the vocabulary is enriched, grammar teaches learners how to combine some word items to create meaningful expressions (Widodo, 2006: 122). Learning the meanings and values of words in different contexts in which they are used furthers the development of vocabulary. Pinker (2020: 20) claims that "we often learn the meaning of words when we hear them in context, not by looking at the dictionary or asking someone." Learning the meaning of a word in context is nothing more than analysing the structural and semantic relationships that make up that context. Such a mental processing both teaches the structure and enriches the individual vocabulary.

Another noticeable awareness is teaching the language to foreigners and/or learning a foreign language. Considering it as a system, while learning the structure of the mother tongue requires taking the same point of view both when teaching others and learning a new language. Language has the character of a system, making it the most effective tool in communication. According to Kiran and Eziler Kiran (2018: 129), if the language did not have the quality of a system, an infinite number of messages would not have been produced and understood only with a pile of words. At the same time, whoever spoke one language could not learn another. Learning a foreign language means sticking the tag of one language to another language, not memorizing the vocabulary or sentence structures, but being able to compare the system with the system of the other language. Decoding the system of the target language and the codes of this language requires a thorough knowledge of the structure and functioning features of the native language. Lack of knowledge in this subject does not enable the learning. For example, Sezer (1979) can only form a sentence in English with three elements, where the subject is Mecnun, the object is Leyla, and the act is determined as love:

Mecnun loves Leyla.

But in Turkish, it is possible to convey the same meaning in six different sentences by combining these three elements as,

Mecnun Leyla'yı seviyor.

Mecnun seviyor Leyla'y1.

Seviyor Mecnun Leyla'y1.

Leyla'y1 seviyor Mecnun.

Seviyor Leyla'yı Mecnun.

Leyla'yı Mecnun seviyor.

He stated that while English sentence formation is based on static syntax, the productivity of Turkish is directly proportional to the variable syntax feature. The sentence in English must be established, because only in this way, it is possible to distinguish between the subject and the task of being an object. However, there are other grammatical signs available in Turkish that show both the subject and the object. With this example, Sezer (1979) emphasized the business and functionality of suffixes in Turkish. Because of these suffixes, the syntax ceases to be static and changes. In Turkish syntax, words do not take on a task by being in special places reserved for them. Only, this kind of grammatical knowledge and ability makes it easier to teach the language to others or to learn a new language.

6. Correct thinking skills and analysing linguistic relationships are discussed under the title of thinking-language relationship. Learning without separating the structural features of language from meaning that influences correct thinking can be explained with the concept of language awareness. The existence of language and knowing how it creates thought with all its possibilities contain all awareness of language. This is also to consider the structure of the language and the functions 
undertaken by the units that make up the structure. "To analyse the structure of the language is to investigate the interchangeability of the parts that make up it" (Vendryes, 2001: 83). In this case, by analysing the contrasts between the parts, different language usages are discovered. According to Larsen Freeman, to understand the difference in language usage, it is necessary to teach the reasons. Because causes tend to be more broadly based than rules. If it is understood why the language user makes the choices, the way of thinking in that language and the culture of those who speak that language is reached (Llantada, 2007:160). Undoubtedly, differences in language use point to differences in way of thinking. Although the difference in the perception of reality and its transmission with language is generally related to the social language, it is also reflected in the way individuals who use the same language concretize their thoughts with various structures. It is a fact supported by the studies of psycholinguists that language has an important role in mental processes such as perception, recall, interpretation, connection, categorisation, and translation (Büyükkantarcioğlu, 2006: 30). Language is a factor in the formation of the mentality. According to Herder, "there are plenty of verb modes in the languages of hard-working nations, and many nouns have turned into abstract concepts in the languages of more developed nations." It is the physiognomy of its language that best reflects the mindset of a nation" (Deutscher, 2013: 11). It can be considered as a noticeable result of the research that learning about grammar creates awareness about the concretization of the structure of the language. Considering that language education is thought education, this result may indicate the existence of an effort towards thought education in grammar teaching.

\section{Conclusions}

In this study, it was tried to determine the awareness of Turkish and the Turkish language and literature prospective teachers' grammar work. According to the findings, the formation of language awareness regarding learning the characteristics of the structure of Turkish language studied by prospective teachers throughout their education, was identified under six main headings as follows: the formation of language consciousness, the development of understanding skills, development of expressive skills, language-reality relationship, functional language use, and thinking-language relationship.

The awareness of mother tongue teacher candidates about their learning in grammar can be considered as an indicator that many of the reasons of grammar teaching stated in the literature have turned into a result. The findings of this research can be evaluated as a feature that increases the originality of the research. With some additions, Hudson's (1992, cited in Aydın, 1997: 24) reasons for grammar teaching can be listed as follows:

- Build linguistic self-esteem and self-confidence,

- To assist the teaching of the standard language,

- Helping to increase students' success,

- Helping to learn a foreign language,

- Increasing linguistic and cultural tolerance,

- To teach the scientific method and analytical thinking,

- Protecting against language abusers,

- Helping to understand language problems,

- To further the general knowledge of the language,

- Creating awareness of the structure of language and the differences in language use, 
- To develop thinking skills by analysing the relationships that make up the structure of the language,

- Transforming the instinctive knowledge of the language into conscious knowledge and language use skills

Since the language skills of the participants were not addressed in this study, it cannot be said that an awareness of the last item was directly reached.

Although the relationship between metalanguage awareness and language use proficiency is the subject of another study, there are studies in the relevant literature claiming that there is no relationship between linguistic ability and language proficiency. For example, in the research conducted by Venuti (2011) with undergraduate students, the expectation that the students' command of the language will increase as their upper language awareness improves, on the contrary, it was seen that the mutual connection between language awareness and language proficiency is quite weak. Borg (1994) emphasizes the desirability of developing awareness of learning/teaching processes as a way of improving teaching and enhancing learner independence (cited in Svalberg, 2007). The results of this study are limited to the mother tongue teacher candidates who make up the sample. Research can be extended with students of different education levels to determine the awareness of the processes of grammar teaching.

\section{References}

Ar1, G., Yıldız, C., Okur, A., \& Yılmaz, Y. (2008). Yeni öğretim programına göre kuramdan uygulamaya Türkçe öğretimi. C. Yıldız (Ed.), Yazma ögrretimi içinde (203-276). Ankara: Pegem Akademi.

Aslan, C. (2017). Örnek eğitim durumlarlyla Türkçe ve Türk dili ve edebiyatı öğretimi. Ankara: Anı Yayıncilik.

Aydın, Ö. (1997). Anadili eğitimi, yabancı dil öğretimi ve evrensel dilbilgisi. Dil Dergisi, 54, 23-30.

Balcı, M., \& Melanlığlu, D. (2020). Ortaokul öğrencilerinin “dil bilgisi”ne ilişkin algılarının söze ve çizime yansıması. Karadeniz Araştırmaları Dergisi, 17(67), 813-834.

Barjesteh, H., \& Vaseghi, R. (2012). Language awareness within the context of changing perspectives on grammar pedagogy, Jurnal Bahasa, Sastra dan Pengajarannya, 6(2), 1-7.

Baş, T., \& Akturan, U. (2013). Nitel araştırma yöntemleri. (2. Baskı). Ankara: Seçkin Yayıncılık.

Batur, Z., \& Beyret, T. N. (2015). Ortaokul öğrencilerinin üst dil farkındalık becerileri ile yazma becerileri arasındaki ilişki, Turkish Studies International Periodical for the Languages, Literature and History of Turkish or Turkic 10(15), 873-892. DOI: http://dx.doi.org/10.7827/TurkishStudies.8982.

Bayraktar, N. (2006). Dilbilim, dil ögretimi. Ankara: Nobel.

Baysen, E., \& Silman, F. (2012). Öğrenme ve öğretme: kuramlar, yaklaşımlar, modeller. Z. Kaya (Ed.) Yapılandırmacı yaklaşım içinde. Ankara: Pegem Yayınları.

Bilgin, N. (2014). Sosyal bilimlerde içerik analizi (3. Baskı). Ankara: Siyasal Kitabevi.

Bogdan, R. C., \& Biklen, S. K. (2006). Qualitative research in (validation) and qualitative (inquiry) studies. It is a method-appropriate education: An introduction to theory and methods.

Bowen, G. A. (2009). Document analysis as a qualitative research method. Qualitative Research Journal, 9(2), 27. 
Börekçi, M. (1997). Türk dilinin en büyük sorunlarından biri: Dilbilimin dil öğretimine yansımamış olmas1. Dil Dergisi, 56, 12-17.

Börekçi, M. (2009). Türkiye Türkçesinde yapı ve işlev bakımından sözcükler. Erzurum: Eser Ofset.

Brimo, D. M. (2011). Examining the contributions of syntactic awareness and syntactic knowledge to reading comprehension. https://www.researchgate.net/publication/232006212 adresinden edinilmiştir.

Brimo, D., Apel, K., \& Fountain, T. (2017). Examining the contributions of syntactic awareness and syntactic knowledge to reading comprehension. Journal of Research in Reading, 40(1), 57-74.

Brown, H. D. (2000). Principles of language learning and teaching (4th ed.). New York: AddisonWesley Longman, Inc.

Büyükkantarcıoğlu, N. (2006). Toplumsal gerçeklik ve dil. İstanbul: Multilingual.

Cain, K. (2007). Syntactic awareness and reading ability: Is there any evidence for a special relationship? Applied Psycholinguistics, 28(4), 679-694.

Can, Ö. (2016). Biçimbilimsel farkındalık ve metnin anlamlandırması: Fransızca yabancı dil sınav metinleri örneği, Uludă̆ Üniversitesi Eğitim Fakültesi Dergisi, 28, (1.Özel Say1), 1-11. DOI: 10.19171/uuefd.88103.

Cansız Aktaş, M. (2014). Nitel veri toplama araçları. M. Metin (Ed.) Kuramdan uygulamaya eğitimde bilimsel araştırma yöntemleri içinde (337-371). Ankara: Pegem Akademik.

Carlisle, J. F. (2000). Awareness of the structure and meaning of morphologically complex words: Impact on reading. Reading and Writing, 12(3), 169-190.

Carter, R. (2003). Language awareness, ELT Journal, 57(1): 64-65, https://doi.org/10.1093/elt/57.1.64.

Charmaz, K. (2015). Gömülü (grounded) teori yapılandırması nitel analiz uygulama rehberi. (2.Baskı) (Hoş, R. Çev.). Seçkin Yayıncılık: Ankara.

Deacon, S. H., \& Kieffer, M. (2018). Understanding how syntactic awareness contributes to reading comprehension: Evidence from mediation and longitudinal models. Journal of Educational Psychology, 110(1), 72.

Deutscher, G. (2013). Dilin aynasından. (Yardımcı, C. Çev:). İstanbul: Metis Bilim Yayıncılık.

Dilber, E. (2015). Dil Öğretimi. (Bekleyen, N. Ed). Dil bilgisi öğretimi içinde. (371-390) Ankara: Pegem Akademi Yayınları.

Ekinci Çelikpazu, E. (2015). Ortaokul 5-8. sınıf Türkçe dil bilgisi öğretimi üzerine bir inceleme. International periodical for the languages, Literature and History of Turkic, 10(15), 333-360.

Er, K., \& Topçuoğlu Ü. F. (2016). Ortaokul öğrencilerine yönelik dil bilgisi tutum ölçeği geliştirilmesi: geçerlilik ve güvenirlik çalışması. Mehmet Akif Ersoy Üniversitesi Eğitim Fakültesi Dergisi, 40, 343-356.

Erkman Akerson, F. (2007). Türkçe örneklerle dile genel bir bakış. İstanbul: Multilingual Yabancı Dil Yayınları.

Flavell, J. H. (1979). Metacognitive and cognitive monitoring: A new area of cognitive developmental inquiry, American Psychologyst, 34, 906-911.

Fraenkel, J. R., Wallen, N. E., \& Hyun, H. H. (2011). How to design and evaluate research in education New York: McGraw-Hill. 
Francis, N. (2002). Literacy, second language learning, and the development of metalinguistic awareness: a study of bilingual children's perceptions of focus on form, Linguistics and Education, 13(3), 373-404.

Güldenoğlu, B., Kargın, T., \& Ergül, C. (2016). Sesbilgisel farkındalık becerilerinin okuma ve okuduğunu anlama üzerindeki etkisi: Boylamsal bir çalışma. Elementary Education Online, 15(1), 251-272. https://doi.org/10.17051/io.2016.25973

Güldenoğlu, B., Kargın, T., Gengeç, H., \& Gürbüz, M. (2019). Okuma sürecinde dil temelli becerilerin önemi: dil - okuma ilişkisine yönelik bulgular, Turkish Journal of Special Education, 1(1), 1-27. DOI: 10.37233/TRSPED.2019.0101

İpek, B. (2015). Bireyde dil bilinci. Journal of Turkish Language and Literature, 1(2) Autumn, 33-44.

Karaağaç, G. (2012). Türkçenin dil bilgisi. Ankara: Akçağ Yayınları.

Kerimoğlu, C. (2017). Genel dilbilime giriş. Ankara: Pegem Akademi.

Kıran, Z., \& Eziler Kıran, A. (2018). Dilbilime giriş. (5. Bask1). Ankara: Seçkin Yayınları.

Korkut, E., \& Ayırır, İ. O. (2016). Dil bilimleri ve dil öğretimi. Ankara: Seçkin Yayınları.

Llantada, M. C. P. (2007). New trends in grammar teaching: Issues and applications an interview with Prof. Diane Larsen-Freeman, Atlantis, 29 (1), 157-163.

Mahony, D., Singson, M., \& Mann, V. (2000). Reading ability and sensitivity to morphological relations. Reading and Writing, 12(3), 191-218.

Martinet, A. (1998). İşlevsel genel dilbilim. (Vardar, B. Çev.), İstanbul: Multilingual Yabancı Dil Yayınları.

MEB. (2019). Türkçe dersi öğretim programı (ilkokul ve ortaokul 1,2,3,4,5,6,7, ve 8. sınıflar). Ankara.

Merriam, S. B. (2013). Nitel araştırma, desen ve uygulama için bir rehber (Turan, S. Çev. Ed.) Ankara: Nobel yayınları.

Mokhtari, K., \& Thompson, H. B. (2006). How problems of reading fluency and comprehension are related to difficulties in syntactic awareness skills among fifth graders. Literacy Research and Instruction, 46(1), 73-94.

Nakatani, Y. (2005). The effects of awareness-raising training on oral communication strategy use, The Modern Language Journal, 89, 76-91.

Onan, B. (2011). Anlama sürecinde Türkçenin yapısal işlevleri. Ankara: Nobel Yayıncılık.

Özkaya, P. G., \& Coşkun, M. V. (2018). Dil bilgisine yönelik tutum ölçeği'nin geliştirilmesi: geçerlik ve güvenirlik çalışması. Ana Dili Eğitimi Dergisi, 6(3), 636-651.

Özsoy, G. (2008). Üstbiliş, Türk Ĕ̈itim Bilimleri Dergisi, 6(4), 713-740.

Patton, M. Q. (2014). Nitel araştırma ve değerlendirme yöntemleri (Bütün, M., \& Demir, S.B. Çev. Ed.). Ankara: Pegem Akademi.

Pinker, S. (2020). Düşüncenin maddesi. (2. Bask1). İstanbul: Alfa Yayınc1lık.

Sayar, F. ve Turan, F. (2012). Okuma gelisiminde üst dil farkındalığı, sesbilgisel süreçler ve bellek süreçlerinin etkisi: Kısa süreli bellek ve çalışma belleği, Ankara Üniversitesi Eğitim Bilimleri Fakültesi Özel Eğitim Dergisi, 13(2) 49-64.

Searle, John R. (2002). Bilinç ve dil (Macit, M., \& Özplavcı, C. Çev). İstanbul: Litera Yayyıncılık.

Sebzecioğlu, T. (2016). Dilbilim kavramlarıyla Türkçe dilbilgisi. İstanbul: Kesit Yayıncılık.

Sezer, A. (1979). Türkçe cümlelerde sözdizimin işlevi. Genel Dilbilim Dergisi, 5(6), 53-63. 
Silverman, D. (2018). Nitel verileri yorumlama (Dinç, E. Çev. Ed.). Ankara: Pegem Akademi.

Snow, C. E., Burns, S. M., \& Griffin, P. (1998). The process of learning to read. preventing reading difficulties in young children. Washington, D. C.: National Academy Press.

Svalberg, A. M. L. (2007). Language awareness and language learning. Language Teaching, 40, 287308. doi:10.1017/S0261444807004491.

Sze, P. \& Leung, F. F. Y. (1998). Enhancing learners' metalinguistic awareness of language form: the use of etutor resources, Assessment and Learning Issue 3, 79-96.

Turgut, Y. (2014). Verilerin kaydedilmesi, analizi, yorumlanmasi: nicel ve nitel. A. Tanrı̈ğen (Ed.), Bilimsel araştırma yöntemleri içinde. Ankara: Anı Yayınları.

Tyler, A. \& Nagy, W. (1990). Use of derivational morphology during reading. Cognition, 36, 17-34.

Vardar, B. (2002). Açıklamalı dilbilim terimleri sözlüğ̈̈. İstanbul: Multilingual Yabancı Dil Yayınları.

Vendryes, J., (2001). Dil ve düşünce (Vardar, B. Çev.) İstanbul: Multilingual Yabancı Dil Yayınları.

Venuti, I. (2011). Metalinguistic knowledge and language proficiency, Psychological Aspects of Language Education, 1-11.

Widodo, H. P. (2006). Approaches and procedures for teaching grammar, English Teaching: Practice and Critique, 5(1), 122-141.

Williams, J. N. (2005). Learning without awareness, SSLA, 27, 269-304.

Yaman, H., \& Karaarslan, F. (2010). İlköğretim Türkçe dersi programının dil bilgisi öğretimindeki etkililiği: nitel bir araştırma. Türkiye Sosyal Araştırmalar Dergisi, 14(1), 251-269.

Yıldırım, A., \& Şimşek, H. (2016). Sosyal bilimlerde nitel araştırma yöntemleri, Ankara: Seçkin Yayıncilik.

\section{AUTHOR BIODATA}

Esra Ekinci Çelikpazu, Recep Tayyip Erdoğan University, Faculty of Education, Department of Turkish and Social Sciences, Rize/Turkey.

Elif Atalay, Atatürk University, Institute of Education Sciences, Erzurum/Turkey. 